\title{
An annual algal diversity of Lakhna, Etawah, Uttar Pradesh, India
}

\begin{abstract}
Omesh Bajpai*
Plant and Environmental Research Institute (PERI), Kanpur (Uttar Pradesh), India

Narendra Mohan

Pryavaran Shodh Ekai, Department of Botany, D. A-V. P.G. College, Kanpur (Uttar Pradesh), India

Jitendra Mohan

Pryavaran Shodh Ekai, Department of Botany, D. A-V. P.G. College, Kanpur (Uttar Pradesh), India

Rajan Kumar Gupta

Centre of Advanced Study in Botany, Banaras Hindu University, Varanasi (Uttar Pradesh), India

*Corresponding author. E-mail: omeshbajpai@gmail.com

Abstract

The nature of an ecosystem can be easily assumed by the presence of planktonic diversity, as they have a major role in oxygen amelioration, binding and removal of toxic substances from water body. The present enumeration deals with the annual algal diversity from the Lakhna town of Etawah, Uttar Pradesh. During this one year period, total fiftyfour species of Algae recorded viz. Achnanthes minutissima, Amphora ovalis, Anabaena oscillarioides, A. oryzae, Ankistrodesmus falcatus, Aphanocapsa littoralis, Aphanothece microscopica, Arthrospira sp., Calothrix gloeocola, Chlorella vulgaris, Chlorococcum humicola, Chroococcus minor, C. minutes, Cladophora glomerata, Closterium venus, Coelosphaerium kuetzingianum, Cyclotella meneghiniana, Cylindrospermum minutissimum, Euglena minuta, Fragilaria crotonensis, Gloeocapsa magma, Gloeotrichia pisum, Gomphonema parvulum, Hydrodictyon reticulatum, Lyngbya contorta, L. epiphytica, L. majuscula, Merismopedia glauca, M. tenuissima, Microcystis aeruginosa, M. flos-aquae, M. robusta, Mougeotia calcarea, Navicula ambigua, N. brebissonii, N. lata, Nostoc commune, N. punctiforme, Oscillatoria formosa, O. subuliformis, O. princeps, Pediastrum boryanum, Phormidium ambiguum, P. fragile, P. lucidum, Rivularia aquatica, Scenedesmus bijuga, S. obliquus, Spirogyra affinis, S. submaxima, Spirulina gigantea, S. major, Ulothrix zonata, Zygnema collinsianum. This information can be used as baseline data and may be further used to assess any change in algal diversity of Gangetic plain after a sufficient gap to understand the impact of changing climate on it.
\end{abstract}

Keywords: Algae, Freshwater bodies, Phycology, Diversity, Lakhna, Etawah, Uttar Pradesh

\section{INTRODUCTION}

The study on the ecology and behavior pattern of plankton in water bodies is a tool to know the ecology and the basic nature of that ecosystem (Singh et al., 2013). Studies on the ecology of plankton of a water body are very helpful to know its general economy and to understand the basic nature of the lake or pond (Devi et al., 2016). The qualitative and quantitative availability of plankton are the result of the interactions between the environmental factors and the organisms (Ramdani et al., 2009). The primary productivity depends upon the photosynthetic trophic level (phytoplankton) and the rest of the biological community including zooplankton depends to a very large extent, on these phytoplanktons (Vallina et al., 2014). The planktons are the direct food of different species of fishes and this relationship in the species composition and their seasonal variability is of great significance (Harris et al., 2012; Hossain et al., 2012; Vajravelu et al., 2018).

The algal diversity of lentic water bodies (ponds, lakes, and reservoir etc.) is very important because it is an important tool to understand its freshness (Patil and Tijara, 2001; Singh and Mathur, 2005; Devi et al., 2016). They have a major role in oxygen enrichment of water, binding and removal of certain toxic substances (Gupta et al., 2015). This type of study also provides a scientific way to manage such type of water bodies. Lentic water bodies (ponds, lakes, and reservoir) are of considerable significance as a source of drinking, domestic, industrial and irrigation waters (Bhateria and Jain, 2016). However, rapid industrialization and urbanization have induced enormous pollution 
and caused severe imbalances in aquatic biology of these water bodies (Trivedy, 1990). These algal contributions are very crucial for water quality improvement (Sen et al., 2013; Bhateria and Jain, 2016). There is an interesting side of lakes, reservoirs and ponds that, their characteristic changes due to seasonal variations which results in the change of water volume, salt concentration, dissolved substances, gases and organic matters and thus in the algal diversity (Bajpai et al., 2013). Considerable amount of work has been done in India about systematic survey, distribution, periodicity and ecology of algae in different habitats from different areas (Misra et al., 2002; Misra et al., 2004; Dwivedi et al., 2005; Tiwari and Chauhan, 2006; Mohan et al., 2007; Misra et al., 2008; Sultana and Gupta, 2009; Suseela and Toppo, 2010; Suresh et al., 2012; Bajpai et al., 2013; Srivastava et al., 2014; Jitendra and Anand, 2016). But, still very little is known about the planktonic diversity of freshwater bodies in different ecological regions. On the bases of literature survey, it appears that no systematic survey has been done in this area of Gangetic plains and so the present work has been taken. Thus, the present study was made on the estimation of algal flora in the water bodies located in Gangetic plains at Lakhna, Etawah, Uttar Pradesh.

\section{MATERIALS AND METHODS}

The different water bodies of Lakhna town, Etawah, Uttar Pradesh were taken for the present study. Sampling was done from several fixed spots in each selected water body. The samples were collected at 30 days interval from the fixed spots. The samples were collected in a wide mouth glass bottle $(500 \mathrm{ml})$ with $5 \%$ formaline and deposited at 'Pryavaran Shodh Ekai', Botany Department, D.A-V. P.G. College, Kanpur. For a detailed study, samples were stained with iodine, mounted in glycerin and examined under the microscope to identify the species. Species identification was done with the help of keys given by (Desikachary, 1959; Prescott, 1964; Prescott, 1976; Anand, 1998).

\section{RESULTS AND DISCUSSION}

The distribution of algae found in the aquatic system showed fifty-four species during our one year study (2008-09). Out of this 31 Cyanophyceae, 14 Chlorophyceae, 8 Bacillariophyceae and 1 Euglenophyceae forms were observed. Such a vast qualitative variance in algal profile is amazing. Detailed examination shows that algae exhibit a high degree of qualitative variance. The occurrence and periodicity of algal species reported are given in table 1.

Similar kind of phytoplanktonic assessment was conducted near Badrinath, Uttarakhand, which reported Chlorophyceae with maximum dominance, followed by Bacillariophyceae, Cyanophyceae, Euglenophyceae, Dinophyceae and Xanthophyceae (Kumar et al., 2012). Generally, Bacillariophyceae are found as dominant group in temperate water bodies (Mir et al., 2007), but the presence of Chlorophyceae here as dominant one clearly indicates the relatively high temperature and nutrient condition. Another study from the Sattur, Tamil Nadu, reported the dominance of Chlorophyceae (Rajagopal et al., 2010). The presence of Chlorophyceae as a dominant group is more related with the water temperature and transparency than any other water property, as both the parameters supports growth of this group (Devika et al., 2006). Findings of this study partially match with the annual planktonic peak concentration for Indian fresh waters bodies and shows maximum number of taxa (44) in the spring i.e. February (Ganpati and Chacko, 1951; Chacko and Krishnamurthy, 1954; Das and Srivastava, 1956; Das, 1959). Listing only one annual peak during the months of spring was also reported by Michael, (1968) and Mukherjee et al., (1995, 2010 ) in their studies and supports the findings of present study. Tiwari and Chauhan, (2006), in his seasonal phytoplanktonic diversity assessment study, reported the dominance of Chlorophyceae, followed by Cyanophyceae from Agra and concluded the good water quality with limited organic matter. Similar kind of reports i.e. presence of higher number of green algae has also been recently reported from fresh water bodies of Central India (Srivastava et al., 2018) and Peninsular India (Pandiammal et al., 2017; Srinivas and Aruna, 2018; Rajyalaxmi and Aruna, 2019). On the other hand the present study shows the dominance of Cyanophyceae members, which may be due to the warmer condition and higher organic matter (Kruger and Elhoff, 1978; Mukherjee et al., 2010). However, the gradual elimination of Chlorophyceae may be the result of an increase in other algae. The present study showed that the incidence of Cyanophyceae in large number indicated by blooms of $\mathrm{Mi}$ crocystis species and Oscillatoria species and also pointing the polluted condition of water bodies in the study area.

\section{Conclusion}

The algal community of the study area is dominated by the Cyanophyceae members, at the same time, certain algae which contribute in degradation of water quality by showing toxic effect (species of Anabaena, Lyngbya and Microcystis), allergenic disease (species of Chlorella, Scenedesmus, Anabaena, Microcystis and Oscillatoria), colour (species of Chlorella, and Microcystis), taste and odor (species of Chlorella, Cladophora, Hydrodictyon, Scenedesmus, Spirogyra, Fragilaria, Anabaena, Nostoc, Oscillatoria and Euglena) are also 
Bajpai, O. et al. / J. Appl. \& Nat. Sci. 11(3): 619- 623 (2019)

Table 1. Annual algal diversity in Lakhna town, Etawah, Uttar Pradesh.

\begin{tabular}{|c|c|c|c|c|c|c|c|c|c|c|c|c|}
\hline Algal Species (2008-09) & Jun. & Jul. & Aug. & Sep. & Oct. & Nov. & Dec. & Jan. & Feb. & Mar. & Apr. & May. \\
\hline Achnanthes minutissima Kützing & + & + & + & - & - & - & - & - & - & - & - & - \\
\hline Amphora ovalis (Kützing) Kützing & + & + & - & + & + & + & + & + & + & + & - & - \\
\hline Anabaena oryzae F.E. Fritsch & - & - & - & + & + & + & + & + & + & + & - & - \\
\hline $\begin{array}{l}\text { Anabaena oscillarioides Bory ex Bornet and } \\
\text { Flahault }\end{array}$ & + & + & - & - & - & - & + & + & + & + & + & - \\
\hline Ankistrodesmus falcatus (Corda) Ralfs & - & - & + & + & - & - & + & + & + & - & - & - \\
\hline Aphanocapsa littoralis Hansgirg & - & - & - & - & + & + & + & + & + & + & - & - \\
\hline Aphanothece microscopica Nägeli & - & - & - & - & - & - & - & + & + & + & + & + \\
\hline Arthrospira sp. & + & - & - & - & - & - & + & + & + & + & + & + \\
\hline Calothrix gloeocola Skuja & - & - & - & + & + & + & + & + & + & + & + & - \\
\hline Chlorella vulgaris Beyerinck & - & - & + & + & + & + & + & + & + & + & - & - \\
\hline Chlorococcum humicola (Nägeli) Rabenhorst & + & - & - & + & + & + & + & + & + & + & + & - \\
\hline Chroococcus minor (Kützing) Nägeli & + & + & + & - & - & - & - & + & + & + & + & + \\
\hline Chroococcus minutes (Kützing) Nägeli & - & - & - & - & + & + & + & + & + & + & + & - \\
\hline Cladophora glomerata (Linnaeus) Kützing & - & - & + & + & + & + & + & + & + & + & - & - \\
\hline Closterium venus Kützing ex Ralfs & - & - & - & - & + & + & - & - & - & - & - & - \\
\hline Coelosphaerium kuetzingianum Nägeli & - & - & - & - & - & - & + & + & + & + & - & - \\
\hline Cyclotella meneghiniana Kützing & + & + & - & - & + & + & + & + & + & + & - & - \\
\hline Cylindrospermum minutissimum Collins & - & - & - & - & + & + & + & + & + & + & + & - \\
\hline Euglena minuta Prescott & - & - & - & - & - & + & + & + & + & + & + & - \\
\hline Fragilaria crotonensis Kitton & + & + & + & - & - & - & - & - & - & + & + & + \\
\hline Gloeocapsa magma (Brébisson) Kützing & - & - & - & - & - & + & + & + & + & - & - & - \\
\hline $\begin{array}{l}\text { Gloeotrichia pisum Thuret ex Bornet \& Fla- } \\
\text { hault }\end{array}$ & - & - & + & + & + & - & - & - & - & - & + & + \\
\hline Gomphonema parvulum (Kützing) Kützing & - & - & - & + & + & + & + & + & + & + & + & - \\
\hline Hydrodictyon reticulatum (L.) Bory & - & - & + & + & - & - & - & - & - & - & - & - \\
\hline Lyngbya contorta Lemmermann & + & + & - & - & - & - & - & - & - & + & + & + \\
\hline Lyngbya epiphytica Hieronymus & - & - & - & - & - & - & - & - & + & + & + & - \\
\hline Lyngbya majuscula Harvey ex Gomont & + & + & - & - & - & - & - & - & + & + & - & + \\
\hline Merismopedia tenuissima Lemmermann & + & + & - & - & + & - & + & + & + & + & - & - \\
\hline Merismopedia glauca (Ehrenberg) Kützing & + & + & + & - & - & - & - & - & + & + & + & + \\
\hline Microcystis aeruginosa (Kützing) Kützing & + & + & + & + & + & + & + & + & + & + & + & + \\
\hline Microcystis flos-aquae (Wittrock) Kirchner & - & - & + & + & + & - & + & + & + & + & - & - \\
\hline Microcystis robusta (H.W. Clark) Nygaard & - & - & - & - & - & - & + & + & + & - & - & - \\
\hline Mougeotia calcarea (Cleve) Wittrock & - & - & - & - & - & - & - & + & + & + & + & - \\
\hline Navicula ambigua Ehrenberg & + & + & - & - & - & - & - & - & - & + & + & - \\
\hline Navicula brebissonii Kützing & - & - & - & - & - & - & - & + & + & + & + & - \\
\hline Navicula lata (Brébisson) Kützing & + & - & - & - & - & - & + & + & + & + & - & - \\
\hline $\begin{array}{l}\text { Nostoc commune Vaucher ex Bornet \& Fla- } \\
\text { hault }\end{array}$ & - & - & - & + & + & + & + & + & + & - & - & - \\
\hline Nostoc punctiforme Hariot & - & - & + & + & + & + & + & + & - & - & - & - \\
\hline Oscillatoria formosa Bory ex Gomont & - & - & - & - & + & + & + & + & + & + & - & - \\
\hline Oscillatoria princeps Vaucher ex Gomont & - & - & - & - & - & + & + & + & + & + & - & - \\
\hline Oscillatoria subuliformis Kützing ex Gomont & - & - & - & + & + & + & + & + & + & + & + & + \\
\hline Pediastrum boryanum (Turpin) Meneghini & - & + & + & + & - & + & + & - & + & + & + & - \\
\hline Phormidium ambiguum Gomont & - & - & - & - & + & + & + & + & + & + & - & - \\
\hline Phormidium fragile Gomont & + & + & - & - & - & - & + & + & - & - & - & + \\
\hline Phormidium lucidum Kützing ex Gomont & - & - & - & - & - & - & - & + & + & - & - & - \\
\hline Rivularia aquatica De Wildeman & - & - & + & + & - & - & - & - & - & - & + & + \\
\hline Scenedesmus bijuga (Turpin) Lagerheim & + & + & + & + & + & + & + & + & + & + & + & + \\
\hline Scenedesmus obliquus (Turpin) Kützing & + & + & - & - & + & + & - & + & + & + & - & + \\
\hline Spirogyra affinis (Hassall) Petit & + & + & + & + & + & + & + & + & + & + & + & + \\
\hline Spirogyra submaxima Transeau & + & + & + & + & + & + & + & + & + & + & + & + \\
\hline Spirulina gigantea Schmidle & - & - & - & - & - & + & + & + & + & + & + & - \\
\hline Spirulina major Kützing ex Gomont & - & - & + & + & + & + & + & + & + & + & + & - \\
\hline Ulothrix zonata (F. Weber \& Mohr) Kützing & - & + & + & + & + & + & + & + & + & + & - & - \\
\hline Zygnema collinsianum Transeau & + & + & + & - & + & + & + & + & + & + & - & - \\
\hline
\end{tabular}

Note: $(+)=$ Presence and $(-)=$ Absent.

reported from the study site. Thus, the study site can be considered to be eutrophic with the mesosaprobic conditions and requires management strategies to improve its water quality. As the study is very first report of algal diversity from the study site, the extracted information from this study can be used as baseline data for climate change and global worming studies. Further, after a sufficient interval of time, one can assess the impact of changing environment on the algal di- versity from the same study area.

\section{ACKNOWLEDGEMENTS}

It is a part of M. Phil. Thesis of the corresponding author. The authors are sincerely grateful to the Principal, D.A-V. P.G. College, Kanpur, India for facilities.

\section{REFERENCES}

1. Anand, N. (1998). Indian Freshwater Microalgae. Bishen Shigh Mahendra Pal Singh Publication, Dehra 
Bajpai, O. et al. / J. Appl. \& Nat. Sci. 11(3): 619- 623 (2019)

Dun, India.

2. Bajpai, O., Mishra, S., Mohan, N., Mohan, J. and Gupta, R.K. (2013). Phyco chemical characteristics of Lakhna Devi temple water tank, Lakhna, Bakewar, Etawah, U.P. with reference to Cynobacterial Diversity. International Journal of Environment 1(1): 20-28. [10.3126/ije.v1i1.8525]

3. Bhateria, R. and Jain, D. (2016). Water quality assessment of lake water: a review. Sustainable Water Resources Management 2(2): 161-173. [10.1007/ s40899-015-0014-7]

4. Chacko, P.I. and Krishnamurthy, K. (1954). On the plankton of three freshwater ponds in Madras. Symposium on marine and freshwater plankton. IndoPacific Council Bangkok. pp. 103-107.

5. Das, S.M. (1959). Studies on freshwater plankton, III: Qualitative composition and seasonal fluctuations in plankton components. Proceedings of the National Academy of Sciences India 29: 174-189.

6. Das, S.M. and Srivastava, V.K. (1956). Quantitative studies on freshwater plankton II. Correlation between plankton and hydrological factors. Proceedings of the National Academy of Sciences India 26: 243-254.

7. Desikachary, T.V. (1959). Cyanophyta, Monograph on blue green algae. I.C.A.R., New Delhi, India, pp. 1 $-689$.

8. Devi, M.B., Gupta, S. and Das, T. (2016). Phytoplankton community of Lake Baskandi anua, Cachar District, Assam, North East India - An ecological study. Knowledge and Management of Aquatic Ecosystems 417: Article number 2 [DOI: 10.1051/ kmae/2015034]

9. Devika, R., Rajendran, A. and Selvapathy, P. (2006). Variation studies on the physico-chemical and biological characteristics at different depths in model waste stabilsation tank. Pollution Research 24: 771-774

10.Dwivedi, S., Misra, P.K., Tripathi, R.D., Rai, U.N., Dwivedi, C.P., Baghal, V.S., Suseela, M.R. and Srivastava, M.N. (2005). Systematic and ecological studies on Chlorophyceae of North India and their relationship with water quality. Journal of Environmental Biology 26: 495-505.

11.Ganpati, S.V. and Chacko, P.I. (1951). Investigation on plankton production and limnology of four fish ponds in Madras. Proceedings of the International Association of Theoretical \& Applied Limnology 11: 111-112.

12.Gupta, C., Prakash, D. and Gupta, S. (2015). Role of Blue Green Algae in Environment Management. In: Ram Prasad (Eds.)., Environmental Microbiology. I.K. International Publishing House Pvt. Ltd., India.

13. Harris, J.M. and Vinobaba, P. (2012) Impact of Water Quality on Species Composition and Seasonal Fluctuation of Planktons of Batticaloa lagoon, Sri Lanka. Journal of Ecosystem \& Ecography 2: 117 [DOI: 10.4172/2157-7625.1000117]

14.Hossain, M.S., Das, N.G., Sarker, S. and Rahaman, M.Z. (2012) Fish diversity and habitat relationship with environmental variables at Meghna river estuary, Bangladesh. Egyptian Journal of Aquatic Research 38(3): 213-226. [10.1016/j.ejar.2012.12.006]

15.Jitendra, P. and Anand, V.K. (2016). Eight new records of fresh water filamentous algae (Oedogonium Link) from India. Tropical Plant Research 3(1): 33-39.

16.Kumar, P., Wanganeo, A., Sonaullah, F. and Wanganeo, R. (2012). Limnological Study on two High Altitude Himalayan Ponds, Badrinath, Uttarakhand. In- ternational Journal of Ecosystem 2(5): 103-111. [10.5923/j.ije.20120205.04]

17.Michael, R.G. (1968). Studies on the zooplankton of a tropical fish pond. Hydrobiologia 31: 47-48.

18.Misra, P.K., Prakash, J. and Srivastava, A.K. (2002). Filamentous green algae from Basti, Uttar Pradesh, India. Phytotaxonomy 2: 130-134.

19.Misra, P.K., Prakash, J., Srivastava, A.K. and Singh, P.K. (2004). Some fresh water planktonic algae from Sant Kabir Nagar, Uttar Pradesh. Phytotaxonomy 4: 87-94.

20.Misra, P.K., Tripathi, S.K., Chauhan, R.S. and Dwivedi, R.K. (2008). Some freshwater Bacillariophycean algae from Yamuna River, Saharanpur, Uttar Pradesh, India. Phytotaxonomy 8: 87-90.

21.Mohan, J., Narain, S., Kumar, H. and Mohan, N. (2007). Diversity of blue green algae in Allen Forest Lake, Zoological Park, Kanpur, mixing with campus sewage. Indian Hydrobiology 10(1): 123-127.

22.Mukherjee, B. and Pankajakshi, G.V.N. (1995). The impact of detergents on plankton diversity in freshwaters. Journal of Environmental Biology 16: 211-218.

23.Mukherjee, B., Nivedita, M. and Mukherjee, D. (2010). Plankton diversity and dynamics in a polluted eutrophic lake, Ranchi. Journal of Environmental Biology 31(5): 827-839.

24.Patil, D.B. and Tijara, R.V. (2001). Studies on water quality of Godchiroli Lake. Pollution Research 20: 257-259.

25.Prescott, G.W. (1964). The fresh water algae. Brown Company Publishers, Dubuque, Lowa.

26.Prescott, G.W. (1976). How to know the fresh water algae. Brown Company Publishers, Dubuque, Lowa.

27.Mir, A.R., Wanganeo, A., Yousuf, A.R. and Wanganeo, R. (2007). Plankton dynamics in relation to fish in Wular lake of Kashmir. Pollution Research 26(4): 733-743.

28.Rajagopal, T., Thangamani, A. and Archunan, G. (2010). Comparison of physico-chemical parameters and phytoplankton species diversity of two perennial ponds in Sattur area, Tamil Nadu. Journal of Environmental Biology 31(5) 787-794.

29.Ramdani, M., Elkhiati, N., Flower, R.J., Thompson, J.R., Chouba, L.M., Kraiem, M.M., Ayache, F. and Ahmed, M.H. (2009). Environmental influences on the qualitative and quantitative composition of phytoplankton and zooplankton in North African coastal lagoons. Hydrobiologia 622(1): 113-131. [10.1007/ s10750-008-9678-4]

30.Sen, B., Alp, M.T., Sonmez, F., Kocer, M.A.T. and Canpolat, O. (2013). Relationship of Algae to Water Pollution and Waste Water Treatment. In: Elshorbagy, W. and R.K. Chowdhury (Eds.)., Water Treatment. Intech Open Limited, London.

31.Singh, R.P. and Mathur, P. (2005). Investigation of variations in physico-chemical characteristics of a fresh water reservoir of Ajmer city, Rajasthan. Indian Journal of Environmental Sciences 9: 57-61.

32.Singh, U.B., Ahluwalia, A.S., Sharma, C., Jindal, R. and Thakur, R.K. (2013). Planktonic indicators: A promising tool for monitoringwater quality (earlywarning signals). Ecology, Environment and Conservation 19(3): 793-800.

33.Srivastava, N., Suseela, M.R. and Toppo, K. (2014). Fresh water cyanobacteria of Sai River near Lucknow, Uttar Pradesh. Tropical Plant Research 1(2): 11 -16 . 
Bajpai, O. et al. / J. Appl. \& Nat. Sci. 11(3): 619- 623 (2019)

34.Sultana, L.H. and Gupta, S. (2009). Phytoplankton diversity and dynamics of Chatla floodplain lake, Barak valley, Assam, North-East India - A seasonal study. Journal of Environmental Biology 30: 10071012.

35.Suresh, A., Kumar, R.P., Dhanasekaran, D. and Thajuddin, N. (2012). Biodiversity of Microalgae in Western and Eastern Ghats, India. Journal of Biological Sciences 15(19): 919-928. [10.3923/ pjbs.2012.919.928]

36.Suseela, M.R. and Toppo, K. (2010). Algae flora of Katarniyaghat Wildlife Sanctuary, District Bahraich in Uttar Pradesh, India. Indian Journal of Forestry 33 (2): 217-220.

37. Tiwari, A. and Chauhan, S.V.S. (2006). Seasonal planktonic diversity of Kitham lake, Agra. Journal of Environmental Biology 27: 35-38.

38.Trivedy, R.K. (1990). River pollution in India. Ashish Publishing House, New Delhi.

39.Vajravelu, M., Martin, Y., Ayyappan, S. and Mayakrishnan, M. (2018). Seasonal influence of physicochemical parameters on phytoplankton diversity, community structure and abundance at Parangipettai coastal waters, Bay of Bengal, South East Coast of India. Oceanologiae 60(2): 114-127. [10.1016/ j.oceano.2017.08.003]

40.Vallina, S.M., Follows, M.J., Dutkiewicz, S., Montoya, J.M., Cermeno, P. and Loreau, M. (2014). Global relationship between phytoplankton diversity and productivity in the ocean. Nature Communication 5 : 4299 [DOI: 10.1038/ncomms5299]

41.Kruger, G.H. and Elhoff, J.N. (1978). The effect of temperature on specific growth rate and activation energy of Microcystis and Synnechococcus isolates relevant to the onset of natural blooms. Journal of the Limnological Society of Southern Africa 4: 9-20.

42.Srivastava, N., Suseela, M.R., Toppo, K. and Lawrence, R. (2018). Fresh water Algal diversity of Central India. International Journal of Research and Development in Pharmacy \& Life Science 7(4): 30393049. [DOI: 10.13040/IJRDPL.2278-0238.7(4).30393049.

43.Srinivas, M. and Aruna, M. (2018). Diversity of Phytoplankton and Assessment of Water in Two Lakes of Telangana State, India. International Journal of Scientific Research in Science and Technology 4(10): 245-256.

44.Pandiammal, S., Manju Bashini, J. and Senthilkumaar, P. (2017). Diversity and Seasonal Fluctuations of Phytoplankton in Temple Pond at Thiruvottiyur, Chennai, South India. Journal of Academia and Industrial Research 6(1): 7-12.

45.Rajyalaxmi, K. and Aruna, M. (2019). Distributional Status of the Diversity of Phytoplankton Population in Fresh Water Lake. International Journal of Scientific Research in Science and Technology 6(1): 227-234. [DOI : 10.32628/IJSRST196131] 